\title{
The quest for public management reform : theory and practice in the case of The Netherlands 1970-1995
}

Citation for published version (APA):

van Mierlo, J. G. A. (1995). The quest for public management reform : theory and practice in the case of The Netherlands 1970-1995. METEOR, Maastricht University School of Business and Economics. METEOR Research Memorandum No. 015 https://doi.org/10.26481/umamet.1995015

Document status and date:

Published: 01/01/1995

DOI:

10.26481/umamet.1995015

Document Version:

Publisher's PDF, also known as Version of record

\section{Please check the document version of this publication:}

- A submitted manuscript is the version of the article upon submission and before peer-review. There can be important differences between the submitted version and the official published version of record.

People interested in the research are advised to contact the author for the final version of the publication, or visit the DOI to the publisher's website.

- The final author version and the galley proof are versions of the publication after peer review.

- The final published version features the final layout of the paper including the volume, issue and page numbers.

Link to publication

\footnotetext{
General rights rights.

- You may freely distribute the URL identifying the publication in the public portal. please follow below link for the End User Agreement:

www.umlib.nl/taverne-license

Take down policy

If you believe that this document breaches copyright please contact us at:

repository@maastrichtuniversity.nl

providing details and we will investigate your claim.
}

Copyright and moral rights for the publications made accessible in the public portal are retained by the authors and/or other copyright owners and it is a condition of accessing publications that users recognise and abide by the legal requirements associated with these

- Users may download and print one copy of any publication from the public portal for the purpose of private study or research.

- You may not further distribute the material or use it for any profit-making activity or commercial gain

If the publication is distributed under the terms of Article $25 \mathrm{fa}$ of the Dutch Copyright Act, indicated by the "Taverne" license above, 


\title{
THE QUEST FOR PUBLIC MANAGEMENT REFORM Theory and Practice in the Case of the Netherlands 1970-1995
}

\author{
Memorandum Prepared for the ACE-PHARE Project \\ 'Can Public Management Innovations as applied in Western Europe and other \\ OECD Countries be applied succesfully in Central and Eastern Europe?' \\ Presented at the Meeting in Budapest, Hungary, 6-15 June 1995 \\ This memorandum has been written with the support of the \\ European Commission's ACE 1994 Programme \\ Research Grant 94-0175-R
}

\author{
J.G.A. van Mierlo \\ Associate Professor of Public Economics \\ Faculty of Economics and Business Administration \\ University of Limburg \\ P.O. Box 616 \\ 6200 MD Maastricht \\ The Netherlands \\ Tel $++3143883641 / 3636$ \\ Telefax ++3143258440
}

Original text May 1995

Revised text August 1995 


\section{Summary}

The Quest for Public Management Reform.

Theory and Practice in the Case of the Netherlands 1970-1995

J.G.A. van Mierlo

Public management reform and public reorganisation are undertaken now for more than two decades in the Western world. These attempts to modernise the institutions in the public sector and their public policies have been inspired by criticisms on big and classical government and on notions of a smaller but better government. Theoretical analysis, empirical research and ideological beliefs are elements in the debate, and many times they are confused

In this research memorandum, the quest for public management reform is described, analysed and evaluated in a case study of the Netherlands for the period 1970-1995. The early beginnings of the reform debate and of reform policies can be traced back to the late nineteen sixties. This resulted in the nineteen eighties in six Big Operations at three levels of the public sector: at the central government level, at the local government level and in the third sector. These operations are in various ways interrelated. The miscellaneous and sometimes even disappointing outcomes of these operations resulted in more modest attempts to public management reform in the nineteen nineties.

This memorandum concludes with a theoretical analysis of the determinants of success and failure of public management reform and public reorganisation. Public management reform is in particular a difficult and complicated learning process, which has to be undertaken in horizontal and democratic policy networks, and in consultations and negotiations with all political actors involved: the politicians as political principals, the bureaucrats as executing agents, and the public as consumers of public service delivery.

\section{Samenvatting}

De Zoektocht naar Hervorming van het Overheidsmanagement. Theorie en Praktijk in Nederland 1970-1995

J.G.A. van Mierlo

Hervorming van het overheidsmanagement en van de organisatie van de overheid wordt reeds twintig jaar in de Westerse wereld ondernomen. De pogingen tot fundamentele hervorming van de organisatie en het management van de overheid vinden hun inspiratiebron in de aanhoudende en radicale kritiek op de grootschalige en klassiek georganiseerde overheid en in het concept van een kleinere maar betere overheid. Theoretische analyse, empirisch onderzoek en politiek-ideologische stellingnamen vormen onderdeel van het debat, maar worden vaak door elkaar gehaald waar zij zouden moeten worden onderscheiden.

In dit research memorandum wordt de speurtocht naar hervorming van de organisatie en het management van de overheid in Nederland beschreven, geanalyseerd en geëvalueerd voor de periode 1970-1995. Het vroege begin van het hervormingsdebat en van het hervormingsbeleid kan worden getraceerd in de late jaren zestig. Een en ander resulteerde uiteindelijk in de jaren tachtig in de zes zogeheten Grote Operaties op drie niveaus van de publieke sector: op het niveau van de centrale overheid, op het niveau van de lokale overheid en in de derde of non-profit sector. Deze operaties hangen onderling op velerlei manier samen. De wisselende en soms ronduit teleurstellende resultaten van deze operaties leidden tot meer bescheiden hervormingspogingen in de jaren negentig.

Dit memorandum sluit af met een theoretische analyse van de succes- en faalfactoren van hervorming van de organisatie en het management van de overheid. Hervorming van de publieke sector is in het bijzonder een moeilijk en gecompliceerd leerproces, dat ter hand genomen moet worden in het kader van horizontale en democratische beleidsnetwerken, en in voortdurend consultatie en onderhandeling met alle betrokken politieke actoren: de politici als opdrachtgevers, de bureaucratische functionarissen als uitvoerders, en het publiek als consumenten van openbare dienstverlening. 


\section{Contents}

1. Introduction

2. Background: criticisms on Big Government

2.1 Changes in administrative organisation of government

2.2 Changes in administrative practice of government

3. Towards a New and Modern Government

3.1 Why smaller but better?

3.2 Some elaboration problems

4. Early beginnings of public management reform

5. Big Operations at the Central Government level

5.1 Characterisation of the Big Operations

5.2 Linkages and conflicts between Big Operations

5.3 Towards an over-arching Big Efficiency-Operation and back

6. Big Operations at the Local Government level

6.1 Characterisation of the local Big Operations

6.2 Provisional balance-sheet of local Big Operations

7. Big Operations in the Third Sector

7.1 Budgeting in second-line health care

7.2 Budgeting in academic education

7.3 Provisional balance-sheet of budgeting operations

8. The issues of the nineteen nineties

8.1 Professionalisation

8.2 Strengthening client orientation

8.3 Improving productivity

9. Conclusion and outlook for 2000 


\section{Introduction}

In the Netherlands, attempts to public management reform and to reorganisation of the public sector are already undertaken as early as since the late nineteen sixties. In politics and administration, public management reform is considered to be part of a larger operation, aiming at fundamental reorganisation of the public sector and of government in general (including also the so-called Third Sector of institutions of non-commercial private initiative). Consequently, in this paper the issue of public management reform in the Netherlands is analysed within the more general framework of reorganisation of the public sector. Public reform processes are going on for more than twenty five years now. It is about time to present a critical assessment of these reform processes, asking questions such as: how far have we come; what did we reach and what not; what can we learn from success, and moreover from failure; what should and can be done in the future? This paper aims at presenting such a critical assessment.

The structure of the paper is as follows. In section 2, criticisms on Big Government, which are a major source of inspiration for public reform processes in many Western countries, are presented. These criticisms result in a plea for a New and Modern Government. The main elements of the definition of New and Modern Government are discussed in section 3. The fourth section is dedicated to a summary of the early beginnings of public management reform in the Netherlands, having started in the nineteen seventies. The nineteen eighties may be considered as the Era of Public Management Reform in the Netherlands: so-called Big Operations were undertaken at the central government level (section 5), at the local government level (section 6) and in the third sector (section 7). The miscellaneous results of these Big Operations stimulated to new directions in the quest for public management reform in the nineteen nineties. These new directions and issues are discussed in section 8 of the paper. Finally, some conclusions are drawn in the last section, section 9, where we present an outlook for public management reform towards the year 2000 and beyond.

In this survey paper, we try to combine a description of public management reform processes in the Netherlands with a critical analysis of the reform process itself: the policy objectives involved, the policy activities undertaken, the results of the reform process, and the determinants of success as well as of failure. In the analysis we apply elements of the theory of public administration, the theory of business administration, and economic theory, in particular welfare economics and public choice theory.

\section{Background: criticisms on Big Government}

Since the end of the Second World War, Western society has undergone structural and fundamental changes: the expansion of the welfare state, economic growth and stagnation, depillarisation, and political emancipation. Due to these changes in society, modern government organisation has changed as well. The organisation of modern government is dominated by 'bureaucracy'. Rosenthal et alii (1987: p. 47) define bureaucracy as "a formal organisational structure characterised by differentiation (division of labour), hierarchy, and holding positions on basis of expertise". 'Bureaucratisation' is the process by which structures and organisations are increasingly developing bureaucratic characteristics. This definition of bureaucracy is related to the classical concept of bureaucracy as developed by Max Weber (Weber, 1947).

\subsection{Changes in administrative organisation of government}

Weber distinguished different types of bureaucracy. The rational type of bureaucracy has attracted the most attention. The 'rational bureaucracy' must be considered form the perspective of Weber's vision on development of society. Bureaucracy and bureaucratisation are part of the more general process of rationalisation of modern society. Rationalisation implies the rise of the monetary economy, of the contractarian society, and of the state based on law.

The bureaucracy-model of Weber implies structural as well as behavioral characteristics. Behavioral characteristics are featured by various forms of discipline and control. 'Formalisation' and 'objectivisation' of rule-making result in bureaucratic behaviour. The bureaucrat does his work with precision and with consistency. Clients are treated anonymously and without prejudice or personal preference ('sine ira et studio'!). However, structural characteristics are the most important in this model. 
As structural features become more dominant, the bureaucratic organisation becomes more rational. This assertion is not true for the behavioural characteristics. Preciseness, consistency and impersonality may at a certain point prevent the realisation of formal organisational goals. Moreover, structural characteristics such as differentiation, hierarchy and recruitment on basis of expertise may coincide quite well with imprecise, inconsistent and personal behaviour of the bureaucrat.

Tensions may be present not only between structural and behavioral characteristics of the Weberian bureaucracy-model, but also between the structural elements themselves. The hierarchical structure may conflict with the principle of expertise. The relation between discipline and expertise can be put under pressure by technological developments, which can be mastered by bureaucrats but not by their superiors. Professionalisation of bureaucrats can cause problems with regard to following orders coming from above, as far as they conflict with patterns of norms and values held by the profession.

This Weberian model of bureaucracy has changed considerably over time. Partly due to the rise of the so-called 'economic bureaucracy-approach' (see Niskanen, 1971), the following bureaucracy definition has become more popular. Economists (e.g. Schütte, 1983) define bureaucracies as organisations which: 1 . apply a budget system; 2 . are not directed by the profit motive; and 3 . do offer their products to buyers (sponsoring politicians and political authorities) and to the public not on a quid pro quo-basis (no voluntary exchange relations), but in a package deal. As far as bureaucrats supply individual (or private) goods - e.g. theatre tickets, gas, water, lecture hours or local waste management -, average costs are calculated. Personnel costs are considered variable. The management takes decisions as intermediary agents of the buyers. The buyers formulate conditions for implementation. Within this framework of conditions, the management of public organisations maximises its own utility function or welfare function (Van den Doel and Van Velthoven, 1990; 1993).

\subsection{Changes in administrative practice of government}

The changes in the definition of bureaucracy (from classical, sociological, Weberian to modern, economical, Niskanian) are the reflections of changes which have occurred in the practice of bureaucratic organisations. In particular four specific changes are important. Firstly, the classical distinction between the political process, in which political decision-making takes place, and public administration, by which political decisions are implemented, has vanished. In the stage of policy preparation and formulation, bureaucrats have much influence because of their professional expertise. The stage of policy implementation contains increasingly elements and moments of political decision-making, because of the fact that not all implementation problems can be predicted or solved at forehand (the concept of 'discretionary power' of bureaucrats). Hence, implementation is also a part of political decision-making and bureaucrats also take part of political decision-making.

Secondly, the size of the public administration has expanded enormously over time, partly due to the increased appeal on government as 'solver of social problems'. In the last decade, various studies on 'the growth of government' have been conducted (Rose 1984; Von Beyme, 1985). They all come to the same conclusion: since 1945, the size of government has expanded rapidly. This growth is shown by five indicators (see also Ringeling, 1984; 1993):

-the number and size of government organisations;

-the number of government employees;

-the tax burden and the share of public expenditure in the gross national product of the economy; -the number of laws and of government programmes;

-the amount of government control of the economy.

In addition, public administration has become much more dynamic, quantitatively as well as qualitatively. With regard to quality, the organisation of government has developed its own dynamics. After a period of unlimited growth, government and public administration have been criticised sharply in the financial-economic crisis of the nineteen eighties. The criticisms of citizens and their organisations on the government for not being able to find political solutions for the financial problems in its own organisation, increase considerably during this decade. These criticisms resulted in serious doubts on the so-called 'make-ability of society' and on the 'problem-solving capacities of government'. After a period of expansive growth, in which only quantitative considerations mattered (more bureaucrats, more budgets, more government organisations, more government activities), the tide changed into the direction of qualitative improvement of the organisation of government. Many attempts to public management and organisation reform aimed not only at a quantitative reduction of the government organisation, but also at qualitative improvement and strengthening. 
Finally, the quantitative expansion of government and of government organisation in the nineteen sixties and seventies has diminished the quality of the organisation of government and its quality of public service. The innate problems of the classical Weberian model of bureaucracy have increased strongly by this expansive quantitative growth. These problems refer to dysfunctional behaviour of bureaucrats, characterised by formalism, red tape, slow handling and the neglect or denial of responsibilities, and so on (Van Braam, 1986: p. 216). Such dysfunctional behaviour of bureaucrats may also be called 'bureaucratism'. Bureaucratism is the regressive outcome of bureaucratic behaviour. Bureaucratism occurs everywhere in the organisation of government, be it in various frequencies and degrees. Bureaucratism has many causes, varying from defects in the bureaucratic organisation, personal defects of bureaucrats, to problems in the relation between citizens and bureaucrats. In particular the defects in the organisation of government are caused by the expansive growth of government. Hence, solutions for the problem of bureaucratism may be sought primarily in the size of the bureaucratic organisation of government.

Hoogerwerf $(1985$, p. 55) proposed the following list of policy measures against bureaucratism. In the first place, measures to decrease the degree of bureaucracy and bureaucratization: less legal bureaucratic power, less bureaucratic hierarchy, less written documents, and less bureaucratic rules. Thus, bureaucracy is lessened and hence bureaucratism is lessened. In the second place, bureaucracy can be fought with separate means: smaller size of the government bureaucracy, less actual power of bureaucrats, less rigorous functioning of bureaucrats. However, the most effective means against bureaucratism appears to be: a smaller organisation of government. All in all, this culminates in a desire expressed very loudly and clearly for a better functioning government, or more generally: a smaller but better government (as advocated by e.g. Osborne and Gaebler, 1993, and analysed critically by e.g. Müller and Wright, 1994; Wright, 1994).

\section{Towards a New and Modern Government}

The reasons for the modern plea for a smaller but better government require some explanation. The backgrounds for this plea refer to a deeply and commonly felt desire for improvement of various aspects and elements of the organisation of government and of public service delivered by the government or under government supervision. The organisation and the public service delivery of government show many deficiencies, which at least partially are caused by the size of the organisation of government. Logical reasoning results then in the requirement, that the size of the government should be decreased in order to improve the quality of the public services delivered to the citizens, because their preferences are the only preferences that should count in a democracy. This implies a reformulation of the wellknown 'postulate of consumer sovereignty' in the market place into a postulate of citizen sovereignty in the public sector. Both statements, a smaller government in order to improve its efficiency and its effectiveness, are combined in the expression: a 'smaller but better government'. Theoretical backgrounds for this notion are formulated by Savas (1987). A summary and analysis is presented by Hughes (1994). Severe criticisms on these theoretical backgrounds have been formulated by Hood and others (1988), Aucoin (1990), Hood (1990 and 1991), Hoggett (1991), Ringeling (1993), Bogdanor (1994) and Stretton and Orchard (1994).

\subsection{Why smaller but better?}

Authors favouring a smaller but better government employ various arguments for their plea. In brief, these arguments all come to the conclusion, that the performance of a smaller governments is considered to better (either absolutely or relatively) than the performance of a larger government.

In the first place, the effectiveness of government policies pursuit by bureaucratic government organisations (directly or indirectly by contracting out) would be increased. Effectiveness refers to the degree, to which policy objectives are realised. Effectiveness implies to best possible connection between the results of public policies (supply, or policy outputs and outcomes) to individual or social demand. Wolfson (1988: pp. 42-43) speaks of 'economic efficiency as criterion for the demand side of public policy'. Secondly, the efficiency of government policies would be improved. Efficiency refers to the cost benefit-ratio of public policies. Public policies are more efficient as the benefits are larger under the assumption of given costs, or the costs are lower under the assumption of given benefits. Efficiency implies the minimalisation of the use of production factors (scarce resources, or policy inputs) 
in the public transformation process: how can we realise a specific policy result with the least possible individual or social costs. Wolfson (1988: pp. 42-43) calls this 'technical efficiency as criterion for the supply side of public policy. Effectiveness or economic efficiency refers to the question: do we the right things? Technical efficiency refers to the question: do we the things right?

In addition to these two more economic standards, two political arguments can be distinguished. A smaller government enables better democratic control (both political and financial-economical), than a larger government. Given the limited span of control of the political management, this double controllability of government organisations for politicians (political representatives and political managers) increases as these government organisations become smaller. Possibilities for discretionary behaviour of bureaucrats and maximalisation of their own welfare function are limited. The results of policy implementation become more in correspondence with the original decisions of the elected politicians. Not only the controllability but also the legitimacy of government organisations will be larger in case of smaller governments than in case of larger governments. Legitimacy of administrative behaviour involves the degree to which this behaviour by the political actors who are confronted by the policy outcomes (the citizens, or the public) is considered to be both legal and just (accepted law). Legitimacy is 'subjective justice' and should be distinguished form 'objective justice' (the degree to which administrative behaviour corresponds with positive law).

These four policy standards for the organisation of government, the first two being more economic and the latter two being more political of character, are related to each other in many ways. A more efficient and effective government organisation with regard to public service delivery may count on a larger legitimacy among the citizens, who have to pay for the services by enforced taxation (and not by voluntary market transactions). In contrast, the legitimacy of the organisation of government can be high even when the efficiency and effectiveness of their public services are considered to be low. Finally, the efficiency and effectiveness of public service delivery are considered to be subjected to the 'economic law of diminishing marginal return': as the size of government increases beyond a certain critical point, this efficiency and effectiveness decreases. The size of the government reaches an optimum, where the marginal benefits of public service delivery (in terms of efficiency and effectiveness) are equal to marginal costs.

\subsection{Some elaboration problems}

The previous reasoning implies, that a larger government does not necessarily mean a better government. To the contrary: beyond a certain optimum point the reverse occurs, where a better public service delivery changes into a worse. Beyond that optimum, a better government changes into a worse government. This argument is valid on the theoretical level, given certain assumptions, but in practice there remain some serious problems to be solved. The formation of public policies for public management reform and reorganisation of government does not follow directly from this logical argumentation.

The first problem concerns both the theoretical and the empirical determination of the exact position of this optimum point. As in the case of determining the optimum point on the well-known Laffer-curve, which expresses the specific relation between the tax structure (in particular the tariff system) and the tax revenue for government, the precise position of the curve expressing the relation between the size of government and the quality of public services delivered by government, is unknown. Empirical measurement is extremely difficult, and that implies that the assumptions underlying hypotheses about the relation between size and quality, become crucial. However, there are as many assumptions as there are people making them, and there as many optima as there are assumptions. Hence, this does not bring us any further.

A second but connected problem arises: when we do not know the precise position of the curve, we also do not know whether the actual size of government is either too large or too small from the perspective of quality of public services rendered. When objective measurement methods are lacking, again different individuals (citizens, politicians, civil servants and scientists) hold different assumptions, and different assumptions produce different outcomes. There is some evidence that in the Western countries we take a position beyond the optimum point on the curve, and consequently the size of 
government should be diminished. On the other hand, there are also arguments for the opposite opinion that we have not reached that optimum point yet and that the size of government should be increased.

Convincing empirical evidence for the one conclusion or for the other is not available yet. In the Dutch 'school' of public administration and of public finance of the University of Twente (Hoogerwerf and Bressers, and Boorsma and Mol, respectively), much empirical research has been conducted to various aspects of the effectiveness and efficiency of public policies and of public provision versus market provision of various goods and services. Many case studies have been reported, but they have not resulted yet in general conclusions about the optimal contents of public policies and about the optimal size and tasks to be performed by government. A comparable conclusion can be formulated for the size and tasks of the non-commercial institutions of private initiative in the Third Sector (see Boorsma and Van Mierlo, 1992).

The history of twenty five years of attempts to public management and public organisation reform in the Netherlands should be approached from this perspective. The general policy objective of a 'smaller but better government' has been a continuous source of inspiration for these attempts. These attempts started as early as in the late nineteen sixties, have been reformulated in the so-called 'Big Operations' in the late nineteen seventies and eighties, and have been reformulated again in the early nineteen nineties under the overarching umbrella of 'Big Efficiency Operation'. The progress of all these attempts has been very slow, mainly due to problems of making political choices, slow procedures of political decision-making, bureaucratic resistance and hesitations in society. The conclusions of empirical research are contradictory and many times disappointing, in particular with regard to criteria as effectiveness and efficiency, political and financial-economic controllability, and democratic legitimacy of government. Probably, approaches to the problem which emphasize economic rationality are insufficient, because they neglect aspects of political rationality and political power, such as the distributive problem of 'winners and losers' (Van Mierlo, 1990).

\section{Early beginnings of public management reform}

Already at the end of the nineteen sixties public management reform in the Netherlands had been placed on the political agenda. 'Reorganisation of the civil service of central government' became a popular theme. We follow here the summary presented by Tjeenk Willink and Hupe (1991). There is a direct connection between the Committee for Interdepartmental Task Distribution and Coordination (in Dutch: 'Commissie Interdepartementale Taakverdeling en Coördinatie', CITC), publishing its first report in 1971, and the Committee Mainstructure of the Central Government Service (in Dutch: 'Commissie Hoofdstructuur Rijksdienst', CHR), reporting ten years later.

Obviously, the functioning of the civil service of central government is considered to be the problem. This problem is generally thought to be concentrated in the stage of policy-formation. The solution is sought in organisational changes. These organisational changes have to be realised at the level of the Cabinet: the Council of Ministers, specific under-councils of this Council, and in interdepartmental committees. The Project Reorganisation of the Central Civil Service (1982-1985), which as part of the Big Operations will be discussed in some detail in the next section, is the follow up of this tradition. This Project also embodied the first attempt to realise substantial changes according to a rational plan, a kind of blueprint. This first attempt to planned change was the direct result of the approach employed by the CHR.

In contrast to the CITC, the CHR finished every stage of its activities with the publication of a report. These reports had the objective to stimulate public reactions and political discussion. Tjeenk Willink and Hupe (1991: p. 22) note some other differences. The CITC limited itself to an inventory of problems in the stage of policy-formation and formulated recommendations for the central civil service as a unity. With political support and bureaucratic cooperation, these recommendations could be executed. The CHR considered the reorganisation of the civil service as a permanent process, whereas the CITC used a programmatic approach. To start the reorganisation process, a separate and temporary provision was necessary. In the opinion of the CHR, reorganisation implies besides organisational measures also a different attitude of persons and hence touches upon the culture of organisations. These structural and cultural elements should be elaborated in a cohesive plan. This cohesive plan had the objective to strengthen the capabilities of the civil service itself for reorganisation in such a way, that the change process at a certain moment could be embedded in the organisation of the central government. 
The attempt to realise real improvements against the background of the solutions suggested by the CHR failed in three respects. Firstly, it was not investigated which conditions have to be fulfilled for successful planned change. It was recognised insufficiently that planned change only is possible when the measures to be taken, the organisation responsible for the implementation process and the organisations which were the object of planned change, are attuned to each other. The selection of the sub-projects (together presented as the 'Plan') and the formation of the project organisation took place along separate lines. Which organisations had to change remained many times unclear. As a consequence, a clear strategy for change could not be developed.

Secondly, serious doubts arose about the power of the analysis and about the effectiveness of the measures recommended by the CHR. On the occasion of the first report of the CHR some critics already asked whether the systems approach adopted in this report was a suitable model for analysis of government organisations.

Thirdly, the CHR during her activities has not been able to follow completely the consequences of its departure of analysis: one organisation of civil service in open connection with its social environment. The problems of just a part of the civil service, the leading top managers, are primary. During the reorganisation process, the relations of the civil service with the political and social environment receive less and less attention. The social environment is considered to be identical with the organisations in society with which government maintains institutionalised contacts, and advisory bodies. In other words, the original external orientation of this first planned public management reform was substituted by a more internal orientation, as the reorganisation process continued.

In a background study by Tjeenk Willink (1980), a different starting point of analysis is employed. In this study the dilemma is recognised, that the government is part of the reorganisation process, and at the same time the manager of change processes and procedures who has to stand above all other parties in the change process (the problem of the 'playing referee'). This dilemma cannot be solved by measures applied only within the central civil service. The political and social environment of the civil service is more than just a difficult side-condition. This recognition has been elaborated further in the reports published by the special government commissioner, who was appointed in 1982 (not surprisingly, this was Tjeenk Willink himself!). In all these reports open relations are a central theme: relations between bureaucrats and politicians, between politics and organisations of society, between these organisations and the civil service. Van Esterik (1987: p. 26) quotes Tjeenk Willink as follows: "These relations never have been the primary object of change. Nobody is responsible for them." The various analyses of the government commissioner Tjeenk Willink have been welcomed with much enthusiasm, but the solutions and remedies he suggested during his time in office never haven been implemented.

\section{Big Operations at the Central Government level}

In the nineteen eighties so-called Big Operations started at three levels of the public sector: at the central government level, at the local government level and in the third sector of non-commercial institutions of private initiative (see Van Mierlo, 1993c). The 'Big Operations' at the Central Government level started under the first Cabinet Lubbers in 1982 (see Van Nispen and Noordhoek, 1986). These big operations at the central government level contain:

1. Reconsiderations of Public Expenditures (Van Nispen, 1993);

2. Reorganisation of the Civil Service of Central Government (Kickert, 1993);

3. Deregulation of Government Intervention;

4. Decentralisation of Central Government Tasks;

5. Deburaucratisation of the Government Organisation (originally defined as the reduction of the number of civil servants at the central government level with -2 percent: the 'minus 2 percent-operation');

6. Privatisation (Andeweg, 1989; 1993).

These big operations are connected to each other with regard to theoretical background as well as in practice: they are interrelated and they strengthen each other when implemented.

\subsection{Characterization of the Big Operations}

The road to the Big Operations in the Netherlands has been paved by political and social developments in the United States and in the United Kingdom, where the role government plays in the economy and 
in society already in the nineteen seventies has been challenged. In these countries this challenge resulted in a radical policy change into the direction of less government and more market ('reaganomics' and 'thatcherism'). A few years later, following these new thoughts on government versus market and following this changing policy-philosophy, the extensive government intervention in economy and society in the Netherlands has been criticised severely in the nineteen eighties (see Van Nispen and Noordhoek, 1986; De Kam and De Haan, 1991).

The first Cabinet Lubbers came into office in 1982. The cabinet started immediately several activities, which later on became known as the six Big Operations. Common source of inspiration for these operations was the desire to adapt the functioning of government to changing opinions about its role and tasks in society. Part of these new activities under the umbrella of Big Operations, however, was not so new as advocated. Some of them already had been started many years before.

The quest for decentralisation is a classical theme in the Dutch debate on (re-)organisation of government (see Toonen, 1987). This quest was labelled 'Big Operation' in 1982. Decentralisation implies that the central government hands over existing public tasks or delegates new public tasks to lower territorial levels of government (provinces or municipalities) or to other functional public institutions (such as Chambers of Commerce, semi-public organisations implementing social security regulations, public water protection and water delivery authorities, public environmental authorities, and so on). The Netherlands have a long tradition in debating decentralisation versus centralisation in the theory and practice of public administration.

In the same way, the Reconsiderations of Public Expenditures already had been undertaken long before the appearance of the first Cabinet Lubbers. In the spring of 1981 the first round of reconsiderations resulted in the selection of thirty important policy areas for a critical re-examination of the necessity of all public activities in these areas and for a search for improvement of their effectiveness and efficiency (see Van Nispen, 1993). Effectiveness of a government activity implies the question to what extent a given policy objective is realised. Efficiency of a government activity implies the question whether the policy outcomes are realised with the least costs or resources. Since then, these so-called 'reconsideration investigations' have been repeated frequently with the purpose, to yield a number of cut down-proposals out of which the policy-makers can make a choice. Reconsiderations have become a constant part of the regular activities of the Ministry of Finance. The yearly Government Budget Proposals contain the results of every new round of reconsiderations.

Deregulation is the third Big Operation and implies the quest for less and less intensive regulations by government. Regulation can be defined as the determination by government authorities of commands or of forbids for firms and households in the private sector of the economy. Almost every regulation contains certain costs. For government these costs are caused by the implementation, the control and the maintenance of regulations (bureaucratic costs). The compliance to regulations also causes costs for producers and consumers. For example: private business plays an important role in the collection of the tax revenues for government (payroll taxes, sales taxes) and in the implementation of social security laws (collection of social premiums, social security payments to employees). Government does not pay for these support activities by private firms, and private firms render these services to government for free. Another example is the continuing intensification of environmental demands. This type of regulation results in larger burdens for firms (investments in purification installations and in clean production technologies) and for consumers (higher prices for cleaner fuel and cleaner cars). Such burdens are sometimes called 'hidden policy costs', which become visible beyond a certain level of 'regulation density'. Deregulation aims at decreasing these hidden costs of regulation, measured in time, in energy as well as in money. The original policy objective of deregulation has been the improvement of the functioning of the market sector. Later on, improving the quality of regulation became the primary objective of deregulation: unnecessary, unworkable and counter-productive rules should be eliminated from the legal system.

The fourth Big Operation is directed towards the Reorganisation of the Civil Service of Central Government. As we have seen above, in the Netherlands the origins of this activity can be traced back to the late nineteen sixties. At the beginning, the policy objective was to improve the steering capacity of central government. Later on, the policy objective shifted towards the management of government organisations. Various organisational measures had to be taken in order to improve the efficiency of the civil service. More emphasis is put on entrepreneurial and market-oriented functioning of government: government should be managed like a private business organisation.

Decreasing the number of civil servants was labelled as the fifth Big Operation. During the first term of office of the Cabinet Lubbers, this was called the 'minus two percent-operation'. During the 
second office term of the Cabinet-Lubbers, the attempt of decreasing the (growth in the) number of civil servants of central government was labelled as the 'cut down-operation'. In the period 1983-1986 this minus two percent-operation resulted in the elimination of 6.100 civil service jobs. During the period 1987-1990, the officially budgeted number of civil service positions was decreased again with 20.000 .

This result has been realised largely (more than 10.000 job positions) by the sixth and last Big Operation, aiming at Privatisation of government tasks. The policy objective of privatisation is to transfer of tasks now performed by government organisations to private business organisations in the market sector, or to change direct government control of certain public tasks into more indirect control. Privatisation has many varieties, for example the direct transfer of public tasks to the private sector, contracting out public tasks to business organisations in the private sector, and making public organisations more autonomous and more independent (in Dutch: 'verzelfstandiging').

\subsection{Linkages and conflicts between Big Operations}

The common label of 'Big Operations' suggests that all the activities under this label are combined into a cohesive package. However, this is not necessarily the case. These operations may contradict each other in many respects and they even may conflict. For instance, experiences in the United States and in the United Kingdom have shown, that privatisation of certain public activities may be accompanied with an extension or an intensification of the amount of regulation. many times, privatisation goes hand in hand with regulation instead of with deregulation. The objective of the public activity to be privatised, would be endangered without supplementary regulation. New methods of regulation, however, cannot be found back immediately in the regulation itself, but fall down in new and less visible forms of government influence (De Ru, 1987: p. 23).

Some cut downs in public expenditures, resulting from reconsiderations, could only be realised by strengthening the control of central government on public activities employed by lower governments. In turn, this strengthened control frustrates the attempts to decentralisation. National standards for social expenditures at the minimum-subsistence level forces central government to limit discretionary power of local governments, in order to control the total amount of public expenditures for this purpose spend by lower governments. These examples show, that the policy objectives of the Big Operations may conflict mutually. For this reason, increasing the discretionary power of local governments is under preparation now in the Netherlands.

In addition to all this, the top management of the Dutch ministries has been confronted with enormous difficulties, because of the fact that Big Operations which were undertaken simultaneously caused coordination problems for the departmental organisations involved. For instance, agreements had to be made about the question, to what extent the results of a particular operation were allowed to be included in the determination of the results of other operations. For this purpose, the net- effects of one ore more operations have to be split up into partial effects, attributed to each distinguished operation separately. The cut down of government (minus two percent-operation) could be realised mainly, because it was agreed upon that the employees of the privatised government organisations had to be included in the realisation of the cut down operation. In fact, the number of public employees has not been decreased really, but many public employees received another legal status, not longer being a civil servant but a (semi) private employee.

De Kam and De Haan (1991: p. 19) state, that the undertaking of big operations implies actually a re-examination of the position and the significance of government intervention in the economy and in society. According to Van Nispen $(1987 ; 1993)$, not the re-examination of the role of government, but the bad financial-economic situation has been the most important argument for starting the big operations at the beginning of the nineteen eighties. At that time it suddenly became clear to everyone, to what extent the financial position of the public sector had been deteriorated in the course of the nineteen seventies. The budget deficit of the Dutch government was estimated about 10 percent of net national income in 1983. Total public debt increases every year with the amount of the budget deficit. Increasing public debt and high interest levels have caused a fast growth of public interest payments during the nineteen eighties. In turn, these expanding public interest payments have crowded out other, probably more useful government expenditures. Reduction of the budget deficit in accordance with a clear and agreed time path received top priority in the financial-economic policies of the first Cabinet Lubbers.

The second Cabinet Lubbers has continued this policy, aiming at a further reduction of the budget deficit. The cabinet followed the same policy with respect to the big operations. According to 
the coalition agreement of the second Cabinet Lubbers, during the period 1987-1990 another 26.000 job positions should be eliminated in the civil service of the central government. Furthermore it was emphasised in the coalition agreement, that in 1990120.000 public employees should loose their status of civil servant as a result of further privatisations. In this period some large privatisation projects have been undertaken (see for a detailed account Andeweg, 1993), such as the partial privatisation of the Postbank (through a merger with the Dutch private bank NMB into the NMB-Postbank and a subsequent merger with the Dutch private insurance company Nationale Nederlanden into the International Netherlands Group ING).

In general, the results and outcomes of the big operations until about 1990 may be considered disappointing. Decentralisation of central government tasks to lower governments (in particular provinces and municipalities) drags on, as has been the case during so many decades before. Political power barriers are responsible for this. In addition this decentralisation is countervailed by the increasing centralisation process within the European Union form the national government levels to the supranational European level. Reconsidering periodically public expenditures has become a routineactivity, but the quantitative effects are not longer spectacular. Deregulation only plays a role in the formation of new regulations and law-making. The reorganisation of the central civil service is limited increasingly to the introduction of techniques for improving public management (self-management and contract-management). This is important of course, but in the beginning much higher ambitions were at stake. The reduction of the number of central government employees is confronted with the counter effects of new public tasks and new public policies (environmental policies, fight against crime). Privatisation appears to have been limited to some large and spectacular projects. In short, in 1990, after two cabinets Lubbers and ten years of big operations, feelings of tiredness and doubts about the sense of it all seem to dominate the political scene.

\subsection{Towards an over-arching Big Efficiency-Operation and back}

When the cabinet Lubbers-Kok comes into office in 1989, the centre-right coalition of Christiandemocrats and conservative Liberals is substituted by an centre-left coalition of Christiandemocrats with Socialdemocrats. In the autumn of 1989, some policy shifts are decided upon. The Minister of Finance has serious doubts about the continuation of the privatisation policies undertaken thus far. In 1990, the personnel cut down-operation came to an end. Instead, the third cabinet Lubbers launched the so-called 'Big Efficiency Operation'. This operation aims at higher efficiency of central government by reducing its tasks, improving its organisational structures and its operations. In the Budget Proposals for 1991 (p. 36) it is stated: "Within this framework, one can think of reorganisations, reshuffling of tasks within and between ministries, deregulation, decentralisation, more autonomy and independence in the implementation of public tasks (if this is more efficient) and a reduction of intermediary tasks". According to this explanation, in this Big Efficiency Operation the various separate conducted big operations of the nineteen eighties are combined.

This does not imply that the various project activities are put to an end. It appears that the Big Operations are continued in another manner. The Advisory Council for the Central Civil Service ('Adviescommisie voor de Rijksdienst', ARD) has published at 27 June 1990 a report titled 'Advice regarding Big Efficiency and Effectiveness of Central Government' ('Advies inzake Grote Efficiency and Effectiviteit Rijksoverheid' (ARD, 1990). In this report, a Big Efficiency Operation is proposed which primarily aims at improvement of the effectiveness and efficiency of the organisation of central government. In this report, a specific connection is made with various forms of territorial and functional decentralisation, various forms of privatisation (autonomous and independent public bodies, selfmanagement and contracting out), public entrepreneurship, deregulation and debureaucratisation. On the occasion of this, the Minister of the Interior mrs. Dales signed a government letter dated 2 October 1990, in which the official start of the Operation 'Big Efficiency' ('Grote Efficiency Operatie', GEO) is announced, headed by a 'Ministerial Committee Efficiency Improvement' ('Ministeriële Commissie Efficiency-Verbetering', MCEV). The policy-objective of this operation was originally defined as a gain of dfl. 300 million in 1994, later on in consultation with the secretaries-general of the departments downgraded to dfl. 150 million. This would result in a decrease of the organisation costs of the departments, of which 60 percent could be spent by the departments themselves in order to stimulate the search for possibilities to improve the quality of the government organisation. In perspective of this relatively small amount of money in 1994 (originally dfl. 300 million, later downgrade to dfl. 150 
million), this operation can be characterised as a relatively small one, certainly in comparison with the ambitious policy objectives of previous separate Big Operations.

At the one hand, in 1989 a policy shift appeared to be prepared. On the other hand, the previous policies seemed to be continued, despite of the political colour change of the cabinet (from centre-right to centre-left). In particular the reduction of the budget deficit remained priority number one. After the cabinet formation, too optimistic estimations of budgetary principles, too optimistic budgetary projections for the future and plain fall backs in government revenues, became apparent in 1990, having serious consequences for the financial situation of the public household. In 1991, a so-called 'Half-term Evaluation' ('Tussenbalans') was made up, in which the policy objective of efficiency improvement was intensified. Thus, the impression of policy continuation was reinforced. Not only the employees of the central government, but also other branches of the public sector were involved. In total, a gain of dfl. 1070 million was budgeted for 1994 . The departments had to contribute dfl. 420 million, the reducing the overhead in the implementation bodies of social security was to yield dfl. 300 million, the health care sector dfl. 300 million and the educational sector df1. 50 million. The reduction of the size of the civil service implied a loss of 9000 job positions. This would change the estimated growth of 2000 job positions in the period 1990-1993 into a decrease of 7000 job positions. In the Budget Proposals for the year 1995, this policy has been continued.

In 1994, the Cabinet Kok came into office, leaning on a coalition of Socialdemocrats (PvdA), progressive Democrats (D66) and the conservative Liberals (VVD). This Purple Coalition of left-right without the Christiandemocrats continues the policies for public management reform of the previous Cabinets Lubbers II and III. It appears that the policy-makers have taken some distance from the oldstyle 'Big Operations'. These operations are no longer labelled as such. De Kam and De Haan (1991: p. 20) signalise a tendency that policy-makers concentrate more on concrete projects. This explains why old policies sometimes receive a new label. For example: many elements of the earlier decentralisationdebate previous can be found back in the debate on public policy formation for social innovation.

The Big Efficiency Operation received the image of a super-operation. This image has not been supported by large quantitative and qualitative policy objectives and policy results. As long as no substantial outcomes are realised, such super-operations are featured by new labels and not by new contents. Geelhoed (1986: p. 59) speaks of 'label fraud', of a verbal exercise, and a magic game with just words. This produces only more mist and confusion around the necessary sanitation and reorganisation of the public sector. Just announcing former Big Operations to be part of a new superoperation Big Efficiency will not turn as such policy failure into policy success. The most important problems remains: what can be done more when even such a super-operation would fail?

The new Cabinet Kok seems to have said farewell to the rhetoric of Big Operations and SuperOperations. Instead, new and more down to earth-initiatives have been taken. For instance: recently, the new cabinet tried to put another long ongoing debate to and end. Starting at 1 July 1995, a General Civil Service ('Algemene Bestuursdienst', ABD) is constituted, headed by a newly appointed DirectorGeneral. The ABD-bureau will be responsible for the management of new routes for professionalisation of top civil servants and for career-development programmes for these civil servants. Horizontal mobility of these top civil servants between the various ministries is an important policy aim. Top civil servants will no longer be appointed as an employee of specific ministry, but in this General Civil Service. Thus, the separation between the ministries, which most likely results in counter-productive 'policy-quivers', is attacked. The British Civil Service served as the main source of inspiration for this constitution of a General Civil Service in the Netherlands (see Kickert, 1993).

In addition, serious deliberations are going on about the separation between policy-making and policy-implementation. Policy-making (including preparations for decision-making: contracting out of policy-preparation and policy-advice is no serious option yet; see Boston, 1994) can be concentrated in smaller ministries, whereas policy-implementation can be transferred to more or less independent executive agencies within or outside the public sector. Many agencies already have been founded in the Netherlands (as a specific form of privatisation; see Andeweg, 1989), which are responsible for policy-execution in various policy-fields (especially public service deliveries at the central level). However, this developement has not resulted yet in considerably smaller ministries. Morover, these agencies are increasingly criticised because of their monopoly positions and practices. Political control of private or semi-public monopolies appears to be more difficult and less effective than political control of political monopolies. 


\section{Big Operations at the Local Government level}

During the nineteen eighties, also at the local government level, by the Dutch municipalities big operations have been undertaken. These local big operations include: financial cut downs, application of the benefit principle, reorganisation, cut down in personnel, deregulation and decentralisation. At the local government level, almost the same big operations as at the central government level are at hand. This can be explained for two reasons. When the central government cuts back its financial contributions to the Municipality Fund ('Gemeentefonds'), the financial resources of the municipalities diminish, as part of the local government income is financed by this fund. Secondly, the first Cabinet Lubbers urged the local governments to support the Big Operations at the central government level by undertaking similar operations at the local government level. This urge has been repeated periodically, by the cabinet as well as by parliament, in order to prevent that the results of big operations at the central government level would leak away at the local government level. Empirical investigations and surveys on big operations at the local government level is scarce in the Netherlands. Our assessment below is based mainly on publications by the Association of Dutch Municipalities ('Vereniging van Nederlandse Gemeenten', VNG, 1986; 1987; 1990) and by Korsten (1993).

\subsection{Characterisation of the local Big Operations}

Let us present a brief characterisation of the Big Operations at the local level. The Financial Cut DownOperation concerns both the revenue side and the expenditure side of the budget. These financial cut down-operations may be described as: "Taking measures on either the revenue side or the expenditure side of the general service budget, in order to assure a balanced budget in times of decreasing budgets" (VNG, 1990: p. 25). These cut downs include incidental measures as well as structural measures, but also general measures and more specific measures. During the nineteen eighties, this cut down operation has been substantial. It started with apolitical, technical measures, which have been supported widely. More radical measures hardly have been necessary. Local cut down policies put more emphasis on limiting expenditures than on expanding revenues. Municipalities have only limited possibilities to collect their own revenues by local taxes, due to their substantial financial dependence on the central government.

The Benefit Principle is located at the revenue side of the budget. Since 1982, municipalities are cut down in their budget transfers out of the Municipality Fund. In the coalition agreement of the Cabinet Lubbers I of 1982, municipalities were supposed to compensate this cut down by applying the benefit principle in the finance of their local public service delivery. The benefit principle implies, that citizens have to pay for public services according to the benefits they derive form them (either through taxation or by paying quasi-market prices). The benefit principle can be applied to some public services but no to other. The principle should be applied for those services, for which citizens can reject consumption and hence for which no consumption force exists (no pure collective goods but quasicollective or individual goods). Through application of the benefit principle, taxes become prices for local public goods and services. During the nineteen eighties, municipalities applied the benefit principle at a large scale. The percentage of costs of public services thus covered has raised substantially. In the meantime, the ideology of the benefit principle has withered away slowly (see VNG, 1990: p. 56). However, this does not prevent local governments from raising their local public prices and taxes continuously, as is shown by research of the VNG and of the National Consumer Association ('Consumentenbond').

Privatisation can be defined as the process by which task, powers and responsibilities of the public sector are diminished in favour of the private sector (VNG, 1990: p. 57). At the local level, various forms of privatisation are undertaken: semi-autonomous and independent public bodies, pushing down, and contracting out. Privatisation is risen from a low position on the political agenda of municipalities in 1979 towards a high position in 1989 and after. In particular the contracting out-variant has been applied frequently. The popularity of the privatisation operation may be explained by the long tradition local governments already had with privatisation of public tasks.

Reorganisation is a big operation which has been undertaken since 1975 in almost every local government. Municipal reorganisations vary widely in size and style, depending on the size of local governments. In particular the classical Dutch 'secretary-services model' has been substituted largely by the modern 'sector' or 'concern model' of the local government organisation. it is difficult to define criteria for success of this operation. Much emphasis is put on policy integration and on the recognition 
of the role of policy sectors in the stages of policy preparation and policy implementation. By consequence, the position of the municipal secretary and of the secretarial department became weaker. This structural change of the local government organisation has been elaborated to its extreme limits in the so-called 'Tilburg-model' (named after the Dutch city Tilburg, where this institutional innovation was developed and practised first).

The Personnel Cut Down Operation regards the number of public employees. A distinction can be made between quantitative cut downs, personnel cut down as qualitative problem, and qualitative change of personnel policy (e.g. introduction of Human Resource Management). In the period 1982-1988 the number of job positions at the local government level has decreased with 19.500 . This amounts to $8,7 \%$ of the total number of personnel (VNG, 1990: p. 75). This down sizing of the municipal labour force is partially caused by other big operations at the local government level, such as financial cut downs. In turn, these financial cut downs have been caused by the reduction of local government revenues (out of the Municipality Fund) by the central government.

Deregulation implies the critical re-assessment of municipal regulations, aiming at elimination or adaptation of local government rules, or at a change in the implementation of these rules. Since 1980, local deregulation does not show any peak or fall. Other subjects probably had more priority. In one out of every five municipalities, deregulation has been undertaken. Various regulations (local government regulations, local police regulations) appeared to be out-fashioned, but conditions for critical investigation were lacking in every two out of three municipalities. In many cases, even an accessible and adequate data-base of local government regulations is lacking: many local governments do not know how much local regulation is present in their own jurisdiction.

\subsection{Provisional balance-sheet of local Big Operations}

In an unpublished paper Korsten (1993: p. 10) has made an inventory of Big Operations at the local government level, which may help us to make up a provisional balance-sheet. At the local government level, there is no sign of a 'retreat of government'. The number of local government tasks seems to have increased instead of decreased. The personnel cut down has not resulted yet in really smaller municipalities. With regard to deregulation, no rigorous cutting in local government regulations has taken place. The financial cut down operation seems to be the most successful.

In the nineteen eighties, governments had to cope mainly with the effects of the reductions of the central government on the Municipality Fund. Initially, these reductions contained incidental measures, but over time they became more structural. During this period, local governments gathered a high expertise in undertaking Big Operations. In particular larger municipalities developed an attitude for critical re-assessments of standing policies, in order to create political and financial possibilities for new policies. These new policies could not stand further delay, such as the maintenance of municipal sewerage or roads, or received political priority, such as public day nursery and environmental policies.

Local governments have attempted to stand united in various local Big Operations and many times they succeeded in these attempts. They did not became involved in lengthy and exhausting political conflicts on these operations. Hence, not surprisingly these operations had mainly a technical and apolitical character (as is confirmed by the reports of the VNG in 1986, 1987, and 1990). Privatisation has not turned out to be a problem of ideological principles, but as an issue that fits in a changing perspective on local governments towards more business-like functioning and more public entrepreneurship. The only exception seems to be the application of the benefit principle in local taxation and local public pricing. Left municipalities try to postpone as long as possible tax raises, for example higher housing rents, in accordance with their left political ideology. The apolitical nature of many Big Operations has not disturbed citizens. Empirical research of Tops et alii (1991) shows, that Dutch citizens are satisfied about the quality of most of the local public service deliveries (but not about their local politicians). Cutting down local government expenses in particular has resulted in a smaller personnel formation. Initially, the effects of this cutting down have been spread over all policy sectors; later on more strategic choices between policy fields have been made.

\section{Big Operations in the Third Sector}

The non-commercial institutions of private initiative in the Third Sector of the economy take in the Netherlands an important position in the execution of public tasks, in particular in the policy fields of 
health care, education, housing, and social services (see Van Mierlo, 1989; 1990b; Van Mierlo and Gerrichhauzen, 1988). In exchange for their responsibility in performing public tasks, they are subsidised (sponsored) by central and local governments. During the nineteen eighties, these private institutions also were involved in big operations. Even more than local governments they were affected directly by the consequences of the Big Operations at the central government level. Financial cut downs, application of the benefit principle, privatisation, reorganisation, personnel cut down, decentralisation, and deregulation: the private institutions had to cope with these operations. On the one hand, they were stimulated or even forced to put their own affairs in order by an ambiguous government (less subsidising and simultaneously more government control). On the other hand new (threats to) competition from firms in the market sector served as an important incentive to do so.

The central government attempted in the nineteen eighties to use the subsidising of private initiative for performing public tasks as a policy instrument to improve the efficiency and effectiveness of the public activities of these institutions. For this purpose, new methods of financing these institutions were developed. The most important new method of finance is so-called external budgeting. The enforcement of a regime of external budgeting may be considered as the most important big operation in the third sector. In this section, two examples of applying external budgeting as a financial management technique for central government towards private institutions are discussed. These two cases are taken from Groot and Van de Poel (1993). They are representative examples of more general developments in the third sector (see for the case of the Netherlands Van Mierlo, 1991b; for an international comparison Gidron et alii, 1992 ). Some of these developments start autonomously and endogenously in the third sector (the private institutions took the inititive themselves); others are initiated by central government.

\subsection{Budgeting in second-line health care}

Second-line health care in the Netherlands contains the hospitals and the nursing-institutions. In the nineteen seventies, production of goods and services in these institutions was accompanied by substantial negative internal effects and dysfunctions. There was a continuous incentive for expanding service provision. Some supervision on the efficiency of service delivery existed, but not on the effectiveness of these services. Decisions were taken by the medical profession and they were financed automatically as a consequence of the so-called 'declaration system'. The expanding costs of second-line health care provisions resulted in the nineteen eighties in government measures. In 1983, the existing system of process budgeting of health care provisions was substituted by a system of input budgeting. This input budgeting, however, had the disadvantage of freezing the unequal original positions of hospital and nursing-institutions for many years. Input budgeting is not suited for dynamic financial adaptations to changing demand. Among the institutions and professionals in the policy field, this resulted in a strong conviction that this budgeting system contained unjust elements. After a few years, the negative reactions of the policy field resulted in the introduction of so-called 'function-oriented budgeting'. In this budgeting method, process characteristics are taken more into account without falling back to a declaration system. The closed end-finance characteristics of this type of external budgeting are combined with elements of process budgeting.

External budgeting, also known as 'task-assigning budgeting', implies that the total budget of a subsidized private institution is restricted a priori to a certain maximum. This maximum is derived from a maximum amount of medical activities (volume-component), multiplied by a certain price factor (price-component). Exceeding the maximum of activities will not be financed by supplementary budget financing of government. Beyond a certain, historically or politically determined maximum, budgets and activities are disconnected. The policy objectives of this disconnection are the following:

1. Control of the cost developments in health care.

External budgeting is considered as an effective policy instrument to stop cost expansions and to realise effective cost cut downs.

2. Decreasing the strongly intensified regulation of the health care system.

External budgeting implies also the elimination of many rules, by which the costs of regulation can be decreased, resulting in a cost reduction without endangering the quality of the service provision. 3. Expanding the local policy discretion of hospitals and nursing-institutions. 
By eliminating detailed rules, hospitals are enabled to take autonomous and independent decisions about the allocation of their resources. resources can be reshuffled between various type of costs and cost, and also between various categories of patients. This also may result in the integration of financialeconomic policies of the hospital and the medical service provisions, by the hospital management and by the medical profession in the hospital.

External budgeting appears to have effected the volumes and the costs of medical production in the Netherlands (as reported by the empirical research of Maarse, 1988; Maarse et alii, 1991). In the nineteen eighties, volume and costs show a shift downwards in the trend. On the other hand, it is not easy to attribute the various financial effects to separate budgeting measures taken by government. Causal relations cannot always be determined empirically or made plausible on theoretical arguments. More-over, it seems necessary to improve the internal planning and control systems of hospitals. This necessity is reinforced by the recent raise in operation costs and by the slow progress of the ongoing system reform in Dutch health care (plan-Simons and after), which will stimulate the local negotiations between suppliers of health care and the financiers (public and private insurers). Due to these developments, the management of the health care institutions will be forced to pursue a coherent policy. In this policy the quality of the service delivery, the effectiveness of medical treatment, and cost notions have to be balanced against each other.

\subsection{Budgeting in academic education}

In the nineteen eighties, the financing system of Dutch universities has undergone various substantial changes. Many of these system changes have been initiated by the central government. His was considered to be necessary, because the government budget for education was decreasing over time and because policy-makers thought it desirable that universities improved their efficiency and effectiveness. The actual situation was as follows. Universities had a strong incentive to keep the students as long as possible (the caricature of 'the eternal student'). There was not information at all about the specific size of activities employed for teaching, for conducting research and for rendering services to society. There was no incentive at all to guard the efficiency and effectiveness of public task performance.

To conquer these problems, two measures were taken by the Ministry of Education. In 1983, a system of conditional finance was introduced, in which output data determined the budget determination for research. The remaining tasks were made visible and were financed in a separate model, the so-called Positions-Money Model ('Plaatsen-Geld Model', PGM). The objective of the PMmodel is to attune budgeting as good as possible to the existing situation of the universities. In the budget determination the university-specific circumstances are taken into account. The corresponding allocation model attempted to approximate as good as possible the real cost structure of academic education and research. However, this attempt resulted in a very complicated budget system. Consequently, university policy-makers were insufficiently able to understand the essentials of the budget system. Because this knowledge was increasingly hampered, the budget allocation could also less and less purposefully be influenced by the behaviour of actors within the universities, the managers and the professionals. Due to these problems, the PM-model lost its function as control instrument. Therefore, at 1 January 1993 an new finance model was introduced, the Higher Education FinanceModel ('Hoger Onderwijs Bekostigingsmodel', HOBEK). The model implied financing by process budgeting. In the HOBEK-model, the emphasis is shifted to output budgeting: numbers of graduates, number of Ph.D.-dissertations, and schools for research. Because of more emphasis on output budgeting, universities have more freedom in selecting the methods for implementation of the public tasks. This built in-tendency is strengthened by the increased freedom for universities to spend the lump sum-budget according to their own policy objectives. The HOBEK-model is less suitable for application as internal budgeting system (only 31 percent of the resources are determined for education activities). Hence, universities have to construct their own internal budgeting models, which correspond better with their own situation. This could reinforce considerably the present-day development towards increasing autonomy of universities.

The new model was also an attempt to make incidental rounds of financial cut down superfluous. The financial instrument of the PM-model had insufficient effect to realise the large financial cut downs which had been decided in the nineteen eighties. In 1983 the operation Task Division and Concentration ('Taakverdeling en Concentratie', TVC, budget gains of dfl. 258 million) 
and in 1987 the operation Selective Shrink and Growth ('Selectieve Krimp en Groei', SKG, budget gains of dfl. 129 million) were implemented. At first sight, these two operations appear to have also other positive effects: more students, more publications, and more contract research. Unfortunately, also negative effects became apparent: less capacity for teachers to accompany the students in their graduation efforts and high administrative costs, the latter due to the disturbance and resistance in the universities provoked by these incidental operations. Quantitative improvements seem to be realised at the cost of qualitative deteriorations. Further improvement of the budgeting techniques is necessary. Improving the budgeting system in the HOBEK-model makes the necessity obsolete to make use of incidental financial cut down operations in times of large financial problems of government.

\subsection{Provisional balance-sheet of budgeting operations}

The effectiveness of budget systems is determined by a complex of factors, which should be taken into account in constructing the system. The diversity of budget systems becomes apparent in comparing different budgeting experiences. In particular the following three factors seem important:

1. The strategy of the budget supplier.

Besides a financial cut down target, government employed various other policy objectives in different branches of the Third Sector. In the second-line health care, external budgeting is introduced (aiming at reduction of the production of health care), whereas in university education a deliberate choice was made for process budgeting (aiming at improvement of education and research).

2. The technical characteristics of the production process of the budgeted institution.

Measurability of output and visibility of the production process determine largely the possibilities for the application of budget systems. In these respects, medical production differs from the production of education and research, and this explains partly the choice for different budget systems in both sectors.

3. The (potential) reactions of the budget receivers to the budget system.

These reactions may be functional (in correspondence with the policy objectives of the budget suppliers), but they also may dysfunctional (in contradiction with these objectives). many adaptations of the budget systems in the second half of the nineteen eighties can be explained by the dysfunctional reactions to the introduction of budget systems in the first half of the nineteen eighties.

\section{The issues of the nineteen nineties}

The Big Operations at the central government level, at the local government level and in the third sector have contributed in the nineteen eighties to more consciousness about the standards demanded to government: the improvement of the organisation and of the policies of government. The main question of the nineteen nineties is, which new issues are on the political agenda of public management as a follow up of these Big Operations. Three major issues dominate the public management reform agenda nowadays: professionalisation of the civil service, strengthening the client orientation and improving the productivity of public organisations.

\subsection{Professionalisation}

Bureaucratic organisations of government are professionalising very rapidly in this decade. Public organisations are subject to the same developments as private organisations. The level of education of the labour force increases due to expansive technological developments at the supply side of the economy. The educational level of civil servants and of public professionals raises correspondently, as the demands imposed by the public and by the politicians on bureaucratic service delivery increases. In 1989 , of the job vacancies for newly recruited civil servants 29 percent was destinated for vocational trained employees and 35 percent for academics. This means that only a minority ( 37 percent) of job vacancies at the level of central government was open for applicants without a higher education (see Ministry of the Interior, 1988 and 1990). This tendency has continued in the nineteen nineties. In addition, re-educationing activities at all levels of civil servants already in government office have 
increased enormously and are now common for every employee. The growth of specific training and education programmes in public administration (measured in number of institutions, courses and students) is spectacular. These are all indicators for a fast professionalisation of the government bureaucracy. Similar developments are going on in the third sector of non-commercial private institutions.

The civil servants and semi-public employees acquire rapidly the habitus of a professional, but this also causes some problems. Professionalisation is hardly compatible with the hierarchical structure of the bureaucratic organisation. Professionalisation implies that the civil servant does his job on basis of professional expertise and can be addressed for doing so. Thus developed and maintained professional values may conflict with the commands given by hierarchical superiors in the bureaucracy. This problem already has been recognised in the economic theory of (business) organisations (refer to various publications of Mintzberg), but there is evidence that government bureaucracies still have insufficient sensitivity and attention for this problem of conflicting competencies.

Handling conflicts between hierarchical competence and professional competence should be part of the professional training of both superiors and subordinates in the government bureaucracy. In the Big Operations of the nineteen eighties, this problem hardly has been recognised, as these operations aimed mainly at changing the bureaucratic structure of government organisations and not their bureaucratic culture. In the nineteen nineties, further professionalisation and changing the bureaucratic culture are essential elements of the concept of 'public entrepreneurship' as advocated by authors as Osborne and Gaebler (1991) and by Dutch public management consultants such as Boer and Croon (De Waal et alii, 1994).

\subsection{Strengthening client orientation}

Increasing client orientation of bureaucratic activities is an important element of the professionalisation of public officials, in particular when these daily activities imply direct contacts with the public. The entrepreneurial business manager, who is forced to continuous client orientation at all levels of the firm by disciplining powers of the market, serves as a model for client orientation of government organisations. On the other hand, this also may aggravate the potential tensions and conflicts between political principals and hierarchical superiors in the bureaucratic organisation, and the public, the clients for whose benefit the professional bureaucrat does his job.

Certainly when the demands of the clients are unclear, ambiguous, or contradictory between different groups of clients, or when the demands of the political principals are contradictory to those of the public, the public employee in question is almost unable to do his work properly. Which demands have to be satisfied, those of the principals or those of the public, and whose preferences will guide the daily activities of the bureaucrat, those of the principals of those of the public? And to which standards and criteria will his activities be judged? Again there is evidence that the bureaucratic government organisation pays insufficient attention to such problems. Civil servants run the risk of being caught in the well-known Catch 22-dilemma: whatever they do, they always do wrong.

This dilemma cannot be solved completely. Either the public is the principal of bureaucrats, just as is the case with private firms in the market sector, and bureaucrats comply to their preferences. Or the sponsoring politicians are the principals and bureaucrats comply to their preferences. Modern public organisations have two masters at the same time. Inherent to public entrepreneurship is the existence of double command structure. When bureaucrats (have to) become public entrepreneurs, they have to learn how to live with this problem and how to handle it. Public management reform in the nineteen nineties should pay much attention to this dilemma.

\subsection{Improving productivity}

Another element of professionalisation is the increasing pressure on the bureaucrat to improve productivity. When the tasks of government grow in number, but the growth of the number of bureaucrats to fulfil this tasks leaps behind, the number of tasks performed by one bureaucrat increases inevitably. Most of the bureaucratic activities consists of public services which are subject to Baumol's law or Baumol's disease.

Baumol (1967) has emphasised the existence of a fundamental dichotomy in the supply structure of the economy: the divergence between sectors with a fast labour productivity growth and sectors with a slow labour productivity growth. Sectors with a fast technological innovation, much accumulation 
of capital and large economies of scale show generally a fast productivity increase. In labour intensive sectors of the economy, in particular in the person related service sector, labour productivity growth generally stays behind. Service production offers less possibilities for improving technological efficiency than industrial production. In addition, there are social and allocative limits to wage differences between both sectors. When quality is constant, the costs of service production will raise relative to the costs of industrial production. The public sector, which is dominated by service production, suffers severely from this slow labour productivity growth. The differential development in labour productivity between the public sector and the (industrial) brings Wolfson (1988: p. 154) to the conclusion that: "this difference may contribute to the development of the public sector into a garbage can of bad bargains". In other words: certainly when bureaucrats work in highly qualified service branches of government, they hardly dispose of possibilities to comply to the increasing pressure of improving their productivity.

In addition, the empirical measurement of their labour productivity is very difficult because of the service character of bureaucratic activities. This difficulty is confirmed by various studies of the Dutch Social and Cultural Planning Office (1989; see also Van de Kar, 1981; 1983; 1984; De Groot and Goudriaan, 1991). If measuring labour productivity of the civil service is hardly possible, it is unreasonable to judge the functioning of bureaucrats on this criterion. Finally, one could argue that it has to go one way or another: if the labour productivity of civil servants can not be increased, the cost of each civil servant have to be decreased by cutting down their salaries. But this does not bring a solution either: where the salaries of civil servants, in particular of those in the higher ranks, diverge to much from salaries earned for comparable (and hence competing on the labour market) work in the market sector, a massive exodus of public employees towards the market sector will take place. Examples are the financial-economic branches (accountants, fiscalists, and organisation consultants) and information-technological sectors (information specialists). The conclusion must of this analysis must be, that government cannot do it on the cheap.

Labour productivity of the civil service is an important theme of public management reform in the nineteen nineties. However, we should not aim too much at labour productivity growth in the public sector, as we have seen that its success will be limited by the effects of Baumol's law. Probably, it may be more profitable that bureaucrats and bureaucratic organisations in the public sector make more money instead of just spending it, by applying a large variety of the benefit principle in prices for public service delivery.

\section{Conclusion and outlook for 2000}

The history and analysis of twenty five years of public management reform attempts in the Netherlands brings us to the following conclusions.

1. As the Big Operations have shown, public management reform is not an incidental attempt. Demands on public organisations, formulated by society and the public, will increase in number and in quality level. These demands also become increasingly more heterogeneous. Even when public management reform would become a permanent phenomenon and activity in the public sector, this will imply that the specific contents and policy objectives of every reform activity will become more varied and more complex: there will be no standard solutions. In a world of continuous change, the management of public organisations will be forced to manage continuous organisational change. Public management reform and public reorganisation will be necessary constantly in order to keep up the strategic management and the innovative capacities of (the management of) public organisations.

2. The results of single public management reform operations will have to be measured and guarded much better. The management of public organisations has to pay more attention to this aspect, but also the political principals and the public have to give this problem more priority. If not, public management reform and public reorganisation will become harmless political rhetoric, without any positive effect on the practice of public administration and public policies. Sooner or later, economic efficiency and effectiveness, as well as democratic support and political legitimacy of public organisations would be endangered.

3. Much more discussion about the contents of public management reforms and public reorganisations, the policy objectives and the policy instruments, and the time path should be organised with the public 
employees involved and with the public and the clients of the public organisations. In modern society, vertical and hierarchical authority relations between the administrators and the administered, between politicians and bureaucrats, bureaucrats and the public, and politicians and the public, are substituted by horizontal, more democratic relations of consultations and negotiations. Bureaucratic commands do not work any more; public solutions for public organisation and public management problems have to be discussed and negotiated with all actors involved. Success or failure of reform operations is determined by active involvement of the professionals within public organisations as well as of the clients and the public outside public organisations. This implies that issues of external management and external relations in public management reform are more important than issues of internal management and internal relations. In addition, public management reform should be managed by a process approach and not by a programme approach. Synoptic-rational planning techniques will have to be substituted by various forms of mixed scanning, interactive planning and cooperation in horizontal policy networks. Success and failure of public management reform and public reorganisation will depend on the support and cooperation of all actors involved, instead of on their distrust and resistance.

4. The most important question remains: will public management reform serve as a tool for administrative innovation in the public sector or as symbol for political rhetoric? The answer depends on the developments discussed under the three conclusions above. The definitive answer will be determined by the search process for a dynamic equilibrium between on the one hand political and administrative ideals and ideologies (which preferences do politicians, bureaucrats and clients, the public, have?) and on the other hand political and administrative interests (how will power relations between various political actors develop?). Decisive is that administrators will keep searching for such a dynamic equilibrium, and that they will learn from their mistakes. The history of public management reform and public reorganisation in the Netherlands shows how difficult this is. This will remain so in the next period to the year 2000 and even beyond. 


\section{References}

Adviescommissie voor de Rijksdienst (ARD), 1990, Advies inzake grote efficiency en effectiviteit rijksoverheid, nr. ARD90/16/U21 (met bijlage), Den Haag 27 juni 1990.

Andeweg, R.B., 1989, Less than nothing? Hidden Privatisation of the Pseudo Private Sector: The Dutch Case, in West European Politics, pp. 117-128.

Andeweg, R.B., 1994, Privatization in the Netherlands: the result of a decade, in V. Wright (ed.), 1994, Privatization in Western Europe. Pressures, Problems and Paradoxes, London, pp. 198-214.

Baakman, N.A.A. en J.G.A. van Mierlo, 1991, Overheid en Onderneming. Een Inleiding, Groningen.

Baumol, W.J., 1967, Macro-Economics of Unbalanced Growth, in American Economic Review, 57, pp. 415-426.

Beyme, K. von, 1985, The Role of the State and the Growth of Government, in International Political Science Review, volume 6 number 1, pp. 12-34.

Bishop, M., J. Kay and C. Mayer (eds.), 1994, Privatization and Economic Performance, Oxford.

Bogdanor, V., 1994, Ministers, Civil Servants and the Constitution, in Government and Opposition: A Quarterly of Comparative Politics, Vol. 29, No. 5, pp. 676-695.

Boorsma, P.B. en J.G.A. van Mierlo, 1992, Doelmatigheid van het maatschappelijk middenveld. Een politiekeconomische beschouwing', in H.M. de Jong en J.J.A. Thomassen (red.), 1992, Tussen Overheid en Samenleving. Bijdragen aan het 21 november 1991 gehouden congres ter gelegenheid van het derde lustrum van de faculteit Bestuurskunde van de Universiteit Twente, Enschede, pp. 149-180.

Boston, J., 1994, Purchasing Policy Advice: the Limits to Contracting Out, in Governance: An International Journal of Policy and Administration, Vol. 7, No. 1, January, pp. 1-30.

Braam, A. van, 1986, Leerboek Bestuurskunde. Tekstboek A, Muiderberg.

Doel, J. van den, 1973, Ekonomie en Demokratie in het Staatsbestuur, Oratie Katholieke Universiteit Nijmegen, Deventer, herdrukt in W.J.Driehuis (red.), 1977, Economische Theorie en Economische Politiek in Discussie, Leiden, pp. 325-358.

Doel, J. van den en B.C.J. van Velthoven, 1990, Democratie en Welvaartstheorie, (derde, geheel herziene druk), Alphen aan den Rijn.

Doel, J. van den and B.C.J. van Velthoven, 1993, Democracy and Welfare Economics, second edition (first edition 1979), Cambridge.

Downs, A., 1967, Inside Bureaucracy, Boston.

Esterik, Chr. van, 1987, Verslag van een Autopsie, in Berichten Regeringscommissaris Reorganisatie Rijksdienst, Den Haag, pp. 21-29.

Fortuyn, W.S.P., 1991, Een Toekomst zonder Ambtenaren, Oratie Erasmus Universiteit Rotterdam, Rotterdam, verkort herdrukt in Economisch-Statistische Berichten, 76 nr. 3795, 13 februari 1991, pp. 172-176.

Geelhoed, L.A., 1986, Deregulering en de grote operaties: achtergronden en vooruitzichten, in F.K.M. van en Nispen en D.P. Noordhoek (red.), 1986, De Grote Operaties. De Overheid onder het Mes of Snijden in Eigen vlees?, Deventer, pp. 35-62.

Gidron, G., R.M. Kramer and L.M. Salaman (eds.), 1992, Government and the Third Sector. Emerging Relationships in Welfare States, San Francisco. 
Groot, H, de en R. Goudriaan, 1991, De Produktiviteit van de Overheid. Over prestaties, personeel en uitgaven in de publieke sector, Schoonhoven.

Groot, T.L.C.M. en J.H.R. van de Poel, 1993, Financieel Management van Non-Profit Organisaties, (tweede druk), Groningen.

Hodgwood, B.W., 1994, A reform beyond compare? The Next Steps restructuring of British central government, in Journal of European Public Policy, Volume 1, No. 1, June, pp. 71-94.

Hoggett, P., 1991, A new management in the public sector?, in Policy and Politics, Volume 19, No. 4, pp. 243256.

Hood, C. (with A. Dunsire and L. Thomson), 1988, Rolling Back the State: Thatcherism, Fraserism and Bureaucracy, in Governance: An International Journal of Policy and Administration, Vol. 1, No. 3, July, pp. 243270.

Hood, C., 1990, De-Sir Humphreyfying the Westminster Model of Bureaucracy: A New Style of Governance?, in Governance: An International Journal of Policy and Administration, Vol. 3, No. 2, April, pp. 205-214.

Hood, C., 1991, A public management for all seasons?, in Public Administration, Volume 69, pp. 3-19.

Hoogerwerf, A., 1985, Een Beleid tegen Bureaucratisme, in H.A. van der Heijden en J. Kastelein (met medewerking van J.Kooiman) (red.), 1985, Succes- en Faalfactoren bij Bestuurlijke Reorganisaties, Groningen, pp. 47-61.

Hughes, O.E., 1994, Public management and public administration, Basingstoke and London.

Kam, C.A. de en J. de Haan (red.), 1991, Terugtredende Overheid: Realiteit of Retoriek? Een evaluatie van de grote operaties, Schoonhoven.

Kar, H.M. van de, 1981, Beheersen en Begroten, in D.J. Wolfson, (red.), Naar een Beheersbare Collectieve Sector, Deventer, pp. 83-124.

Kar, H.M. van de, 1983, Het Meten van Overheidsvoorzieningen, in Maandblad voor Accountancy en Bedrijfshuishoudkunde, 57, pp. 280-292.

Kar, H.M. van de, 1984, De Toegevoegde Waarde van Overheidsvoorzieningen, Bijdrage Studieconferentie Interfaculteit Bedrijfskunde, Rijksuniversiteit Groningen, 'Ontwikkelingen rond het begrip toegevoegde waarde', 24 en 25 mei 1984, Rotterdam.

Kickert, W.J.M. (red.), 1993, Veranderingen in Management en Organisatie bij de Rijksoverheid, Alphen aan den Rijn.

Korsten, A.F.A., 1993, Grote bestuurlijke operaties in gemeenten, ongepubliceerd manuscript Rijksuniversiteit Limburg, Maastricht.

Korsten, A.F.A., F. Kluytmans, T.W.P.M. van der Krogt en A. Sorber (red), 1991, Overheidsmanagement en de menselijke factor, Congrespublicatie 1991 van de Vereniging voor Bestuurskunde, 's-Gravenhage.

Korsten, A.F.A. en Th.A.J. Toonen (red.), 1988, Bestuurskunde. Hoofdfiguren en Kernthema's, Leiden.

Le Grand, J. and W. Bartlett (eds.), 1993, Quasi-Markets and Social Policy, Basingstoke and London.

Maarse, J.A.M., 1988, Budgettering van Ziekenhuizen. Aspecten, trends en effecten, Oratie Rijksuniversiteit Limburg, Maastricht.

Maarse, J.A.M., A. van der Horst en E.J.E. Molen, 1991, Budgettering in algemene ziekenhuizen. Effecten op de Zorgverlening, Maastricht.

Mierlo, J.G.A. van, 1988a, Pressiegroepen in de Nederlandse Politiek. Controleren Pressie- en Belangengroepen Nederland?, (SMO-boek), Den Haag. 
Mierlo, J.G.A. van, 1988b, Ambtelijk gedrag in Bureaucratische Organisaties. Het Werk van Antony Downs, in A.F.A. Korsten en Th.A.J. Toonen, (red.), Bestuurskunde. Hoofdfiguren en Kernthema's, Leiden, pp. 229-253.

Mierlo, J.G.A. van, (red.), 1989, Particulier Initiatief in de Klem. Gemangeld tussen Politiek en Bedrijfsleven?, Lochem.

Mierlo, J.G.A. van, 1990a, Rationalisering van het Overheidsbeleid, in Beleidswetenschap, 4 nr. 3, pp. 254-267.

Mierlo, J.G.A. van, 1990b, Privatization and the Third Sector of the Economy. A Public Choice Perspective, in Annals of Public and Cooperative Economics, 61 nr. 4, pp. 537-560.

Mierlo, J.G.A. van, 1991a, Ambtelijke posities en rollen in verandering: een overzicht, in A.F.A. Korsten, F. Kluytmans, T.W.P.M. van der Krogt en A. Sorber (red), 1991, Overheidsmanagement en de menselijke factor, Congrespublicatie 1991 van de Vereniging voor Bestuurskunde, ‘s-Gravenhage 1991, pp. 157-181.

Mierlo, J.G.A. van (red.), 1991b, Particulier Initiatief in de Gezondheidszorg, Assen/Maastricht.

Mierlo, J.G.A. van, 1993a, Ambtelijk ondernemerschap als innovatieve managementstrategie in de publieke sector, Research Memorandum 93-007, Rijksuniversiteit Limburg, Maastricht.

Mierlo, J.G.A. van, 1993b, Ambtelijk ondernemerschap in contacten met klantgroepen en belangengroepen, in A.J.G.M. Bekke, F. van Dijk, A.P.M. Schrijvers, N. Wijma en G. Wijnen (red.), Handboek Management in Overheidsorganisaties, Alphen aan den Rijn 1993, pp. A3140-1 - A3140-26.

Mierlo, J.G.A. van, 1993c, Grote Operaties in de publieke sector. Bestuurlijke vernieuwing of politieke symboliek?, Research Memorandum 93-041, Rijksuniversiteit Limburg, Maastricht, September 1993.

Mierlo, J.G.A. van, 1994, Learning Processes between Public and Private Organisations, Research Memorandum RM 0/94-058, Meteor, Faculty of Economics and Business Administration, Limburg University, Maastricht December 1994.

Mierlo, J.G.A. van en L.G. Gerrichhauzen (red.), 1988, Het Particuliere Initiatief in de Nederlandse Verzorgingsmaatschappij. Een Bestuurskundige Benadering, Lochem en Gent.

Mierlo, J.G.A. van, J.H. van der Made en P. de Jong (red.), 1993, Gezondheidszorg in de Jaren Negentig. Op weg naar maatschappelijk ondernemerschap?, SISWO publikatie 376, Amsterdam.

Ministerie van Binnenlandse Zaken, 1990, Start operatie grote efficiency. Kabinetsstandpunt ARD-advies, Den Haag 2 oktober 1990.

Ministerie van Financiën, Miljoenennota 1991, ‘s-Gravenhage.

Ministerie van Financiën, Miljoenennota 1994, 's-Gravenhage.

Ministerie van Financiën, Miljoenennota 1995, 's-Gravenhage.

Müller., W.C. and V. Wright (eds.), 1994, The State in Western Europe. Retreat or Redefinition?, Special Issue of West European Politics, Volume 17 Number 3, July.

Niskanen, W.A., 1971, Bureaucracy and Representative Government, Chicago.

Nispen, F.K.M. van, 1987, De heroverweging is een schouwtoneel: elk speelt zijn rol en krijgt zijn deel, RISBOpublikatie, Rotterdam.

Nispen, F.K.M. van, 1993, Het Dossier Heroverweging, Delft.

Nispen, F.K.M. van en D.P. Noordhoek (red.), 1986, De Grote Operaties. De Overheid onder het Mes of Snijden in Eigen vlees?, Deventer.

Osborne, D. and T. Gaebler, 1992, Reinventing Government. How the Entrepreneurial Spirit is Transforming the Public Sector, Reading MA.

Overheid en Arbeidsmarkt 1988, Ministerie van Binnenlandse Zaken, Den Haag. 
Overheid en Arbeidsmarkt 1990, Ministerie van Binnenlandse Zaken, Den Haag.

Ringeling, A.B., 1984, Dynamiek van Overheidsbemoeienis: groei in tal en last, in J.W. de Beus en J.A.A. van Doorn (red.), 1984, De Interventiestaat. Tradities-Ervaringen-Reacties, Meppel en Amsterdam, pp. 117-137.

Ringeling, A.B., 1993, Het Imago van de Overheid, 's-Gravenhage.

Rose, R., 1984, Understanding Big Government, London

Rosentha1, U, M.P.C.M. van Schendelen en A.B. Ringeling, 1987, Openbaar Bestuur. Organisatie, Politieke Omgeving en Beleid, (vierde geheel herziene druk), Alphen aan den Rijn.

Ru, H.J. de (red.), 1987, Privatisering in de Praktijk, Zwolle.

Savas, E.S., 1987, Privatization. The Key to Better Government, Chatham N.J.

Schütte, H.G., 1983, De Dilemma's van Bureaucratieën met Professionele Staf, in S. Lindenberg en F.N. Stokman (red.), 1983, Modellen in de Sociologie, Bundel aangeboden aan prof. dr. I. Gadourek ter gelegenheid van zijn vijfentwintigjarig jubileum als hoogleraar Sociologie aan de Rijksuniversiteit te Groningen, Deventer, pp. 62-74.

Sociaal en Cultureel Planbureau (SCP), 1989, Doelmatig Dienstverlenen, Sociale en Culturele Studie nr. 11, Rijswijk.

Stretton, H. and L. Orchard, 1994, Public Goods, Public Enterprise, Public Choice. Theoretical foundations of the contemporary attack on government, Basingstoke and London.

Tjeenk Willink, H.D. en P.L. Hupe, 1991, Reorganisatie Rijksdienst, in C.A. de Kam en J. de Haan (red.), 1991, Terugtredende Overheid: Realiteit of Retoriek? Een evaluatie van de grote operaties, Schoonhoven, pp. 21-38.

Tjeenk Willink, H.D., 1980, Regeren in een Dubbelrol, Achtergronmdstudie nr. 1, uitgebracht aan de Commissie Hoofdstructuur Rijksdienst, Den Haag.

Toirkens, S.J., 1988, Schijn en Werkelijkheid van het Bezuinigingsbeleid, 1975-1986, Deventer.

Toonen, Th.A.J., 1987, Denken over Binnenlands Bestuur. Theorieën van de gedecentraliseerde eenheidsstaat bestuurskundig beschouwd, 's-Gravenhage.

Tops, P.W. e.a., 1991, Lokale democratie en bestuurlijke vernieuwing in Amsterdam, Den Haag, Utrecht, Eindhoven, Tilburg, Nijmegen en Zwolle. Samenvatting van een onderzoek in zeven gemeenten, Delft.

Tullock, G., 1965, The Politics of Bureaucracy, Washington.

Tussenbalans 1991, Tweede Kamer, vergaderjaar 1990-1991, 21998 nr. 2:6 en nrs. 27-28.

Vereniging van Nederlandse Gemeenten VNG, 1987, Gemeente en deregulering, Den Haag 1987.

Vereniging van Nederlandse Gemeenten VNG-SGBO, 1986, Gemeentelijke Heroverwegingen I, Den Haag.

Vereniging van Nederlandse Gemeenten VNG-SGBO, 1990, Gemeentelijke Heroverwegingen II, Den Haag.

Waa1, S.P.M. de, Th.N.M. Schuyt en P.A. Verveen, 1994, Handboek Maatschappelijk Ondernemerschap, Houten/Zaventem.

Weber, M., 1947, The Theory of Social and Economic Organization, (transl. Parsons/Henderson), New York.

Wersch, P.J.M. van, 1980, Democratisering van het Bestuur van Non-Profit Instellingen, Alphen aan den Rijn.

Wright, V. (ed.), 1994, Privatization in Western Europe. Pressures, Problems and Paradoxes, London.

Wolfson, D.J., 1988, Publieke Sector en Economische Orde, Groningen. 